\title{
Establishing the correlation between soil and crop production to optimize wine quality
}

\author{
$\underline{\text { A. Perez-Kuroki }}^{\text {a }}$, S. Shanmuganathan ${ }^{\text {a }}$, F. Scannavino Jr. ${ }^{\text {, }}$ P. Sallis a ${ }^{\text {and A. Narayanan }}{ }^{\text {c }}$ \\ ${ }^{a}$ Geoinformatics Research Centre, School of Computing and Mathematical Science, \\ Auckland University of Technology, New Zealand \\ ${ }^{b}$ Physics Institute of São Carlos - IFSC, University of São Paulo, São Carlos, Brazil \\ ${ }^{c}$ School, School of Computing and Mathematical Science \\ Auckland University of Technology, New Zealand \\ Email: ana.perezkuroki@aut.ac.nz
}

\begin{abstract}
The inherent correlation between soil composition and viticulture productivity is complex and methodologies available are either labour intensive or requires significantly expensive technologies, such as precision viticulture. In this context, the paper elaborates on research that investigated in to establishing the correlation between soil nutrient distribution and soil type using 3-dimentional distribution models. Plant productivity and quality data collected from the vineyard are analysed to obtain weighted correlation of all factors being considered. Field monitoring from spring to autumn (October 2010/May 2011) has been conducted in a commercial vineyard located in Kumeu, New Zealand. Data collected include soil samples at strategic locations and yield production and sugar content of berries at the same specific sites for two grape varieties (Chardonnay and Pinot Noir). Soil properties were collected at three different horizons for a total of 58 sites (137 samples). Chemical experiments were conducted on the soil samples to establish the soil $\mathrm{pH}$, Nitrate, Sodium and Potassium.
\end{abstract}

Preliminary results show a slight difference between the availability of nutrients at different layers of soil in the vineyard. The spatial analysis at two different depths showed the top layers with lower $\mathrm{pH}$ values than bottom layers. In addition a significant correlation was found on Sodium, Nitrate and yield in relation to the elevation, slope and depth. Environmental conditions were an important factor on yield productivity at plant level, revealed by the Pearson's and Spearman's correlation $(\mathrm{r}=0.408$; $\mathrm{rho}=0.388)$, but a minor factor at field level (T-pair Sig (2.tailed) value of 0.397 ) when considering orientation of the plant. Figure 1 shows the locations where the yield was collected and the total yield produced per site (in $\mathrm{Kg}$ ). From the map, it is evident that there is an $18^{\circ}$ shift of the field from the true south-north direction, favouring the eastern branches of the vine which produced $10 \%$ more than the western side.

Finally, geostatistical analysis to obtain accurate nutrient distribution maps using interpolation techniques to relate the nutrients with plant performance and berry quality are presented.

Keywords: Soil nutrient, grapevine, geostatistical analysis

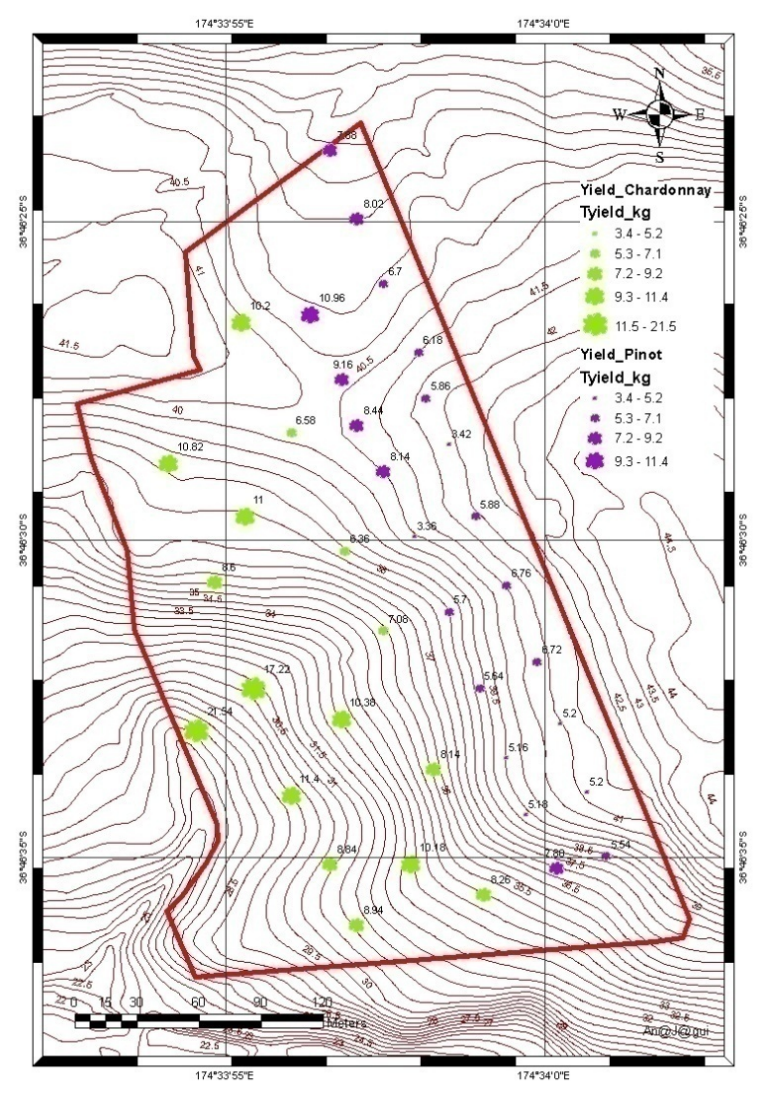

Figure 1. Sampling sites and yield production per site (considering 4 plants at each site) 


\section{INTRODUCTION}

Understanding the factors relating to the successful production of high quality wine grapes has been the main target for winemakers. Climate is commonly recognized as the main driving force for the success of the wine industry, hence determining the ideal conditions under which wine regions and their varieties prosper is considered as vital for producing premium quality wine. Nevertheless there are additional factors that come into play at micro-scale (often expressed in meters rather than kilometres as it happened at macro-scale level). These factors are related to soil properties of the area including soil texture, composition, hydrological factors and water availability. The significance of soil fertility and it impacts on vine has been widely studied (CRS 95/1, 2002), including the influence of the vineyard design and environment (Gee, 2011; Jackson and Lombard, 1993). However, a comprehensive spatial distribution study including all the parameters influencing grapevine growth has not been performed at this stage in New Zealand and the paper presents such a study in view of the importance of geospatial aspects in grapevine yield and wine production.

\section{METHODOLOGY}

Site and Samples:

Data used in this study was collected in two series of experiments: (i) Soil nutrient data at 3 different horizons (depths) from equally distributed sampling sites across a field of 5.2ha at Kumeu River Winery, New Zealand $\left(36^{\circ} 46^{\prime} 30^{\prime \prime} \mathrm{S} 174^{\circ} 34^{\prime} 0^{\prime \prime} \mathrm{E}\right)$, collected in October 2010; (ii) plant yield at particular locations, collected during March, 2011 (same sites where soil samples were taken) from a 10year-old Pinot Noir and 7 to 9-year-old Chardonnay varieties.

Total number of soil samples studied on the experiment (i) was 137 samples from 58 sites. From depths labelled as horizon A $(5 \sim 15 \mathrm{~cm}$ depth) and horizon B (15 25cm depth) samples were collected at each site; at horizon $\mathrm{C}$ $(25 \sim 35 \mathrm{~cm}$ depth) samples were collected at specific sites only (every other site). Chemical experiments (Table 1) were performed for each soil sample to obtain $\mathrm{pH}$, Sodium $(\mathrm{Na})$, Potassium $(\mathrm{K})$ and Nitrate $\left(\mathrm{NO}_{3}\right)$. Soil samples were collected using a $5-\mathrm{cm}$ diameter cast iron auger, immediately after extraction the soil $\mathrm{pH}$ was measured with a Field Scout pH 110 Meter Data Logger, then sealed in clean plastic bags and taken to the lab for further analysis. Once in the laboratory the samples were air dried to minimize biological transformation and other chemical reactions, plant and root material were removed, they were ground and passed through a $1 \mathrm{~mm}$ sieve, finally they were bagged, labelled and stored in a dry and cool place until chemical experiments were performed.

Vine yield data for the experiment (ii) was collected from the four vines closest to selected soil sampling sites. A total of 152 vines, out of $12793(\sim 1.2 \%$ of the vine population on a vineyard with a density of 2460vines/ha) were used in this study. The selected vines are termed as the North-East (NE), North-West (NW), South-East (SE) and South-West (SW)
Table 1. Equipment and protocol followed during experiments.

\begin{tabular}{|l|l|l|}
\hline Element & Equipment & Protocol followed from: \\
\hline Soil pH & $\begin{array}{l}\text { Field Scout } \mathrm{pH} 110 \text { Meter } \\
\mathrm{pH} \text { meter }\end{array}$ & $\begin{array}{l}\text { Spectrum (a) } \\
\text { Hill and Sparling, 2009 }\end{array}$ \\
\hline Sodium & Cardy Sodium Na+ Meter & Spectrum (b) \\
\hline Potassium & Cardy Potassium K+ Meter & Spectrum (c) \\
\hline Nitrate & Cardy Twin Nitrate Meter & Spectrum (d) \\
\hline
\end{tabular}
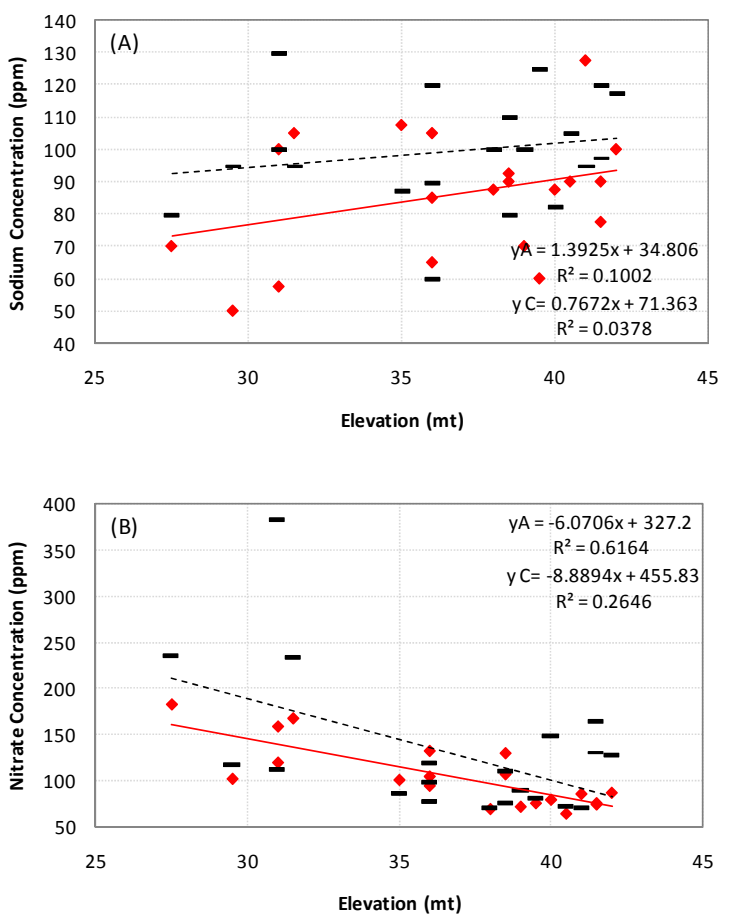

Figure 2. (A) $\mathrm{Na}$ concentration and (B) $\mathrm{NO}_{3}$ concentration vs. site elevation at Kumeu River Winery studied field; depths between 5 15cm ( $\diamond$ : Horizon A) and $25 \sim 35 \mathrm{~cm}$ (-: Horizon C). 
based on directions with respect to the soil sampling sites. Each vine has two cordons (branches), one facing East (E) and the other facing West (W) from a U or Lyre trellis system array (Smart and Robinson, 2006). Collected data consist on the amount of berries (in $\mathrm{Kg}$ ) that each vine produced per cordon. Other physical characteristics of the vine and its production were collected such as number of bunches per cordon, number of berries per bunches; also sugar content, $\mathrm{pH}$ and weight of representative sampled berries. In addition, it was calculated the $\%$ of sand, silt, and clay of the soil, the temperature and moisture of undisturbed soil measured at each site. Only part of these datasets will be used for this paper.

\section{Numerical Analysis:}

The statistical analysis of the database aims at identifying the correlations existing between the measured parameters $\left(\mathrm{pH}, \mathrm{NO}_{3}, \mathrm{~K}, \mathrm{Na}\right.$ and yield) and inherent location related parameters (elevation, sunshine, weather, etc). Descriptive statistics is carried out to characterize the dataset, including minimum, maximum and mean values are calculated in addition to their dispersion and distribution using the following general equations:

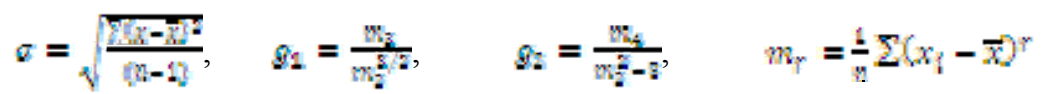

Where $\sigma$ is the standard deviation used to calculate the dispersion and its square value is the variance of that dataset; $\mathrm{x}$ and $\bar{x}$ are the value and its mean, $n$ is the total number of samples. Regardless of the smaller standard deviation, its distribution should be carefully considered as tailed values could introduce interesting correlations. Moreover, a measurement describing the shape of the distribution is given by $\mathrm{g}_{1}$ and $\mathrm{g}_{2}$, skewness and kurtosis respectively (Joanes and Gill, 1998); a measure of asymmetry or skewness close to zero is stated to be indicating a normal distribution; in contrast to a positive or negative value which could normally reveal a right or left tail (values more than twice its standard error represent departure from symmetry). On the other hand, a measure of peakness or kurtosis is used to evaluate the extent of the values clustered around a central point; positive values represent a sharper peak and longer tails, with the opposite for negative values.

Correlation models were utilized to obtain the statistical dependence of parameters studied in this research (linear and non-linear). To evaluate the strength of the relationship between variables, Pearson's productmoment correlation coefficient and Spearmans's rank correlation (Spearmans's rho) were used for its linear and non-parametric measure of dependency, respectively (Rodgers and Nicewander, 1988; Potvin and Roff, 1993).

The data analysis is performed in three stages: First stage by performing statistical analysis of all nutrient data obtained in the experiment (i) and finding the relationships within the data set. Second stage is performed by exploring the vine yield data collected during experiment (ii), considering the orientation and topography of the vineyard. Final stage consists of comparisons between the interpolated results from the soil data and total yield per site.

Table 2. Descriptive Statistics of relevant parameters extracted from Kumeu River Winery field. Each parameter was measure at two different depths, between $5 \sim 15 \mathrm{~cm}$ (horizon A) and $25 \sim 35 \mathrm{~cm}$ (horizon C). Plant density of 2460 vines/ha.

\begin{tabular}{|c|c|c|c|c|c|c|c|c|c|c|c|c|c|}
\hline & \multirow[t]{2}{*}{ ID } & \multirow[t]{2}{*}{$\mathrm{N}$} & \multirow[t]{2}{*}{ Min } & \multirow[t]{2}{*}{ Max } & \multirow[t]{2}{*}{ Sum } & \multicolumn{2}{|c|}{ Mean } & \multirow{2}{*}{$\begin{array}{c}\text { Std. } \\
\text { Deviation }\end{array}$} & \multirow[t]{2}{*}{ Variance } & \multicolumn{2}{|c|}{ Skewness } & \multicolumn{2}{|c|}{ Kurtosis } \\
\hline & & & & & & Statistic & Std. Er & & & Statistic & Std. Er & Statistic & Std. Er \\
\hline Elevation & & 20 & 28 & 42 & 734 & 36.68 & 0.99 & 4.43 & 19.59 & -0.71 & 0.51 & -0.67 & 0.99 \\
\hline \multirow{4}{*}{$\begin{array}{l}\text { Yield } \\
(\mathrm{Kg})\end{array}$} & NE plant & 20 & 0.64 & 6.98 & 48.30 & 2.42 & 0.33 & 1.49 & 2.22 & 1.59 & 0.51 & 3.71 & 0.99 \\
\hline & NW plant & 20 & 0.80 & 3.58 & 40.56 & 2.03 & 0.16 & 0.73 & 0.53 & 0.36 & 0.51 & -0.30 & 0.99 \\
\hline & SE Plant & 20 & 0.12 & 6.40 & 44.92 & 2.25 & 0.31 & 1.39 & 1.93 & 1.86 & 0.51 & 4.42 & 0.99 \\
\hline & SW plant & 20 & 1.14 & 4.58 & 44.02 & 2.20 & 0.20 & 0.91 & 0.83 & 1.70 & 0.51 & 2.89 & 0.99 \\
\hline \multirow{2}{*}{$\begin{array}{c}\mathrm{pH} \\
(\mathrm{ppm})\end{array}$} & A Horz & 20 & 5.34 & 5.92 & 112.90 & 5.65 & 0.04 & 0.18 & 0.03 & -0.07 & 0.51 & -1.23 & 0.99 \\
\hline & C Horz & 20 & 5.22 & 6.43 & 117.42 & 5.8710 & 0.07 & 0.30 & 0.09 & 0.07 & 0.51 & 0.05 & 0.99 \\
\hline \multirow{2}{*}{$\begin{array}{c}\mathrm{Na} \\
(\mathrm{ppm})\end{array}$} & A Horz & 20 & 50.0 & 127.5 & 1717.5 & 85.88 & 4.35 & 19.47 & 379.13 & -0.01 & 0.51 & -0.20 & 0.99 \\
\hline & C Horz & 20 & 60 & 130 & 1990 & 99.50 & 3.91 & 17.46 & 305.00 & -0.16 & 0.51 & 0.03 & 0.99 \\
\hline \multirow{2}{*}{$\begin{array}{c}\mathrm{K} \\
(\mathrm{ppm})\end{array}$} & A Horz & 20 & 10 & 150 & 933 & 46.63 & 9.31 & 41.63 & 1733.08 & 1.16 & 0.51 & 0.28 & 0.99 \\
\hline & C Horz & 20 & 0 & 140 & 560 & 28.00 & 8.26 & 36.96 & 1366.18 & 2.22 & 0.51 & 4.47 & 0.99 \\
\hline \multirow{2}{*}{$\begin{array}{c}\mathrm{NO}_{3} \\
(\mathrm{ppm})\end{array}$} & A Horz & 20 & 65 & 183 & 2091 & 104.56 & 7.65 & 34.22 & 1170.93 & 1.01 & 0.51 & 0.14 & 0.99 \\
\hline & C Horz & 20 & 70 & 383 & 2596 & 129.81 & 17.10 & 76.48 & 5849.55 & 2.25 & 0.51 & 5.70 & 0.99 \\
\hline
\end{tabular}


Perez-Kuroki et al., Establishing the correlation between soil and crop production to optimize wine quality

\section{RESULTS}

Statistical Analysis:

The summaries of statistical parameters considered in the research are shown on Table 2. Data at similar depth and locations were grouped to analyse the correlations at these depths being studied. From their descriptive statistics it is not possible to draw any conclusions or obtain any evidence on any parametric dependency with each other or with the soil depth.

Table 3. Statistical analysis of relevant parameters considering Pearson's Correlation and Speaman's rho coefficient. Each parameter was measure at two different depths, between $5 \sim 15 \mathrm{~cm}$ (horizon A) and $25 \sim 35 \mathrm{~cm}$ (horizon C).

\begin{tabular}{|c|c|c|c|c|c|c|c|c|c|c|c|c|c|}
\hline & & \multicolumn{2}{|c|}{ Elev } & \multicolumn{2}{|c|}{$\mathrm{pH}$} & \multicolumn{2}{|c|}{$\mathrm{Na}$} & \multicolumn{2}{|c|}{$\bar{K}$} & \multicolumn{2}{|c|}{$\mathrm{NO}_{3}$} & \multicolumn{2}{|c|}{ Yield } \\
\hline & & Horz A & Horz C & Horz A & Horz C & Horz A & Horz C & Horz A & Horz C & Horz A & Horz C & Horz A & Horz C \\
\hline \multirow{4}{*}{ Elev } & Pearson Correlation & 1 & 1 & 0.001 & -0.136 & 0.194 & 0.316 & -0.093 & -0.071 & $-0.514^{*}$ & $-0.785^{* *}$ & $-0.750^{* *}$ & $-0.750^{* *}$ \\
\hline & Sig. (2-tailed) & & & 0.996 & 0.568 & 0.411 & 0.174 & 0.696 & 0.765 & 0.020 & 0.000 & 0.000 & 0.000 \\
\hline & Spearman's rho Correlation & 1.000 & 1.000 & 0.009 & -0.030 & 0.278 & 0.219 & -0.002 & 0.117 & -0.235 & $-0.710^{* *}$ & $-0.768^{* *}$ & $-0.768^{* *}$ \\
\hline & Sig. (2-tailed) & \#NULL! & \#NULL! & 0.970 & 0.900 & 0.236 & 0.354 & 0.995 & 0.623 & 0.318 & 0.000 & 0.000 & 0.000 \\
\hline \multirow{4}{*}{$\overline{\mathrm{pH}}$} & Pearson Correlation & 0.001 & -0.136 & 1 & 1 & $0.502^{*}$ & -0.064 & 0.074 & 0.045 & 0.044 & 0.056 & -0.090 & -0.034 \\
\hline & Sig. (2-tailed) & 0.996 & 0.568 & & & 0.024 & 0.789 & 0.758 & 0.849 & 0.855 & 0.815 & 0.704 & 0.886 \\
\hline & Spearman's rho Correlation & 0.009 & -0.030 & 1.000 & 1.000 & $0.489^{*}$ & 0.001 & -0.049 & 0.022 & 0.020 & -0.005 & 0.047 & -0.036 \\
\hline & Sig. (2-tailed) & 0.970 & 0.900 & \#NULL! & \#NULL! & 0.029 & 0.997 & 0.837 & 0.926 & 0.932 & 0.985 & 0.845 & 0.880 \\
\hline \multirow{4}{*}{$\mathrm{Na}$} & Pearson Correlation & 0.194 & 0.316 & $0.502^{*}$ & -0.064 & 1 & 1 & 0.303 & 0.060 & 0.232 & -0.004 & -0.316 & -0.359 \\
\hline & Sig. (2-tailed) & 0.411 & 0.174 & 0.024 & 0.789 & & & 0.194 & 0.802 & 0.324 & 0.986 & 0.174 & 0.120 \\
\hline & Spearman's rho Correlation & 0.278 & 0.219 & $0.489^{*}$ & 0.001 & 1.000 & 1.000 & 0.133 & 0.026 & .042 & 0.072 & -0.371 & -0.142 \\
\hline & Sig. (2-tailed) & 0.236 & 0.354 & 0.029 & 0.997 & \#NULL! & \#NULL! & 0.576 & 0.915 & .862 & 0.764 & 0.108 & 0.551 \\
\hline \multirow{4}{*}{ K } & Pearson Correlation & -0.093 & -0.071 & 0.074 & 0.045 & 0.303 & 0.060 & 1 & 1 & 0.394 & 0.137 & 0.061 & 0.330 \\
\hline & Sig. (2-tailed) & 0.696 & 0.765 & 0.758 & 0.849 & 0.194 & 0.802 & & & 0.086 & 0.565 & 0.799 & 0.156 \\
\hline & Spearman's rho Correlation & -0.002 & 0.117 & -0.049 & 0.022 & 0.133 & 0.026 & 1.000 & 1.000 & -0.210 & -0.006 & 0.175 & 0.085 \\
\hline & Sig. (2-tailed) & 0.995 & 0.623 & 0.837 & 0.926 & 0.576 & 0.915 & \#NULL! & \#NULL! & 0.375 & 0.980 & 0.461 & 0.722 \\
\hline \multirow{4}{*}{$\mathrm{NO}_{3}$} & Pearson Correlation & $-0.514^{*}$ & $-0.785^{* *}$ & 0.044 & 0.056 & 0.232 & -0.004 & 0.394 & 0.137 & 1 & 1 & 0.244 & $0.609^{* *}$ \\
\hline & Sig. (2-tailed) & 0.020 & 0.000 & 0.855 & 0.815 & 0.324 & 0.986 & 0.086 & 0.565 & & & 0.300 & 0.004 \\
\hline & Spearman's rho Correlation & -0.235 & -0.710 & 0.020 & -0.005 & 0.042 & 0.072 & -0.210 & -0.006 & 1.000 & 1.000 & 0.018 & $0.566^{* *}$ \\
\hline & Sig. (2-tailed) & 0.318 & 0.000 & 0.932 & 0.985 & 0.862 & 0.764 & 0.375 & 0.980 & \#NULL! & \#NULL! & 0.940 & 0.009 \\
\hline \multirow{4}{*}{ Yield } & Pearson Correlation & $-0.750^{* *}$ & $-0.750^{* *}$ & -0.090 & -0.034 & -0.316 & -0.359 & 0.061 & 0.330 & 0.244 & $0.609^{* *}$ & 1 & 1 \\
\hline & Sig. (2-tailed) & 0.000 & 0.000 & 0.704 & 0.886 & 0.174 & 0.120 & 0.799 & 0.156 & 0.300 & 0.004 & & \\
\hline & Spearman's rho Correlation & $-0.768^{* *}$ & $-0.768^{* *}$ & 0.047 & -0.036 & -0.371 & -0.142 & 0.175 & 0.085 & 0.018 & $0.566^{* *}$ & 1.000 & 1.000 \\
\hline & Sig. (2-tailed) & 0.000 & 0.000 & 0.845 & 0.880 & 0.108 & 0.551 & 0.461 & 0.722 & 0.940 & 0.009 & \#NULL! & \#NULL! \\
\hline
\end{tabular}

Information obtained from this table shows that $\mathrm{pH}$ values are within normal range for grape production (Dami et al., 2005), however potassium (K) and Sodium (Na) are significantly lower than the average values reported on general soil samples for Northern areas of NZ (Kim and Taylor, 2009). Nevertheless, related literature reveals that higher concentration of potassium on the soil could affect directly on the quality of the grapes in terms of colour and $\mathrm{pH}$ (Deb, 2011; Rouhana, 2010) and the recommended soil K levels for vineyards is between 75 to 100ppm (Bates and Gee, 2011).

Although, the descriptive statistics did not reveal any correlation between parameters, it should be noted that those parameters and their distributions (skewness and kurtosis) are not normal. From Table 2, it is evident that Yield, $\mathrm{K}$ and $\mathrm{NO}_{3}$ show a right tail and rounder distribution.

Further statistical analysis conducted using the same parameters are shown on Table 3, based on Pearson's correlation (r) and Spearman's rho (rho) of this table it is evident that there is a relationship in the variability of certain parameters across the vineyard. The relationships found between Sodium concentrations against elevation and those of Nitrate against elevation, are consistent to some previously reported behaviour (White, 1987; Selim et al., 1983; Ioka et al., 2001). Positive correlations found on the Sodium-Elevation relation (Figure 2A), is explained when salt ions $\left(\mathrm{Ca}^{2+}, \mathrm{Mg}^{2+}, \mathrm{Na}^{+}\right.$, etc) rise to upper layers due to evaporation, either from groundwater sources or irrigation practices.

It then appears that the results on this study are in line with the literature. The upper layer (Horizon A) $\mathrm{Na}$ concentration change faster with elevation, meaning that at higher areas evaporation occurs faster. Nevertheless, based on the comparisons of the Na concentrations at different depths, it is evident that this trend is not consistent with the evaporation theory, which could be due to different soil type and its corresponding percolation coefficient, which will have to be further studied.

On the other hand, Nitrate concentrations are associated with polluted rivers and groundwater from runoff and leaching leading to higher concentrations of pollutants in the area (Elrashidil et al., 2005; Ocampoa et al., 
Table 4. Simple rule to identify orientation preferences of the plants: If $\mathrm{Y}_{\mathrm{E}}>\mathrm{Y}_{\mathrm{W}}$ then $\mathrm{c}=1$ otherwise $\mathrm{c}=0$. Plant yield is in $\mathrm{Kg}$ per branch.

\begin{tabular}{|c|c|c|c|c|c|c|c|c|c|c|c|c|}
\hline \multirow{2}{*}{$\mathrm{ID} /$} & \multicolumn{2}{|c|}{ Plant yield } & \multirow[t]{2}{*}{ C } & \multicolumn{2}{|c|}{ Plant yield } & \multirow[t]{2}{*}{ C } & \multicolumn{2}{|c|}{ Plant yield } & \multirow[t]{2}{*}{ c } & \multicolumn{2}{|c|}{ Plant yield } & \\
\hline & & & & & & & & SWE & & & SEE & \\
\hline & 1.12 & 1.12 & 0 & 54 & 0.30 & 0 & 1.32 & 1.44 & 1 & 1.02 & 0.92 & \\
\hline 2 & 0.96 & 0.42 & 0 & 1.14 & 1.00 & 0 & \begin{tabular}{|l|}
1.64 \\
\end{tabular} & 0.70 & 0 & 1.00 & 1.16 & \\
\hline 3 & 1.34 & 0.86 & 0 & 0.48 & 0.54 & 1 & 0.78 & 0.98 & 1 & 0.70 & 1.02 & \pm \\
\hline 4 & 0.58 & 0.98 & 1 & 0.30 & 0.66 & 1 & 1.38 & 0.74 & 0 & 0.78 & 0.76 & \\
\hline 5 & 0.92 & 0.74 & 0 & 0.44 & 0.66 & 1 & \begin{tabular}{|l|}
0.54 \\
\end{tabular} & 0.62 & 1 & 0.74 & 1.20 & 1 \\
\hline 6 & 0.28 & 0.34 & 1 & 0.28 & 0.44 & 1 & 0.50 & 0.52 & 1 & 0.46 & 0.60 & \pm \\
\hline 7 & 0.58 & 0.92 & 1 & 0.70 & 0.66 & 0 & 0.72 & 1.14 & 1 & 0.42 & 0.74 & \\
\hline 8 & 0.34 & 0.46 & 1 & 0.48 & 1.62 & 1 & 1.00 & 0.84 & 0 & 0.98 & 1.04 & \\
\hline 9 & 1.10 & 0.34 & 0 & 0.70 & 1.18 & 1 & 0.84 & 0.90 & 1 & 0.78 & 0.88 & 1 \\
\hline 10 & 0.28 & 0.78 & 1 & 0.42 & 0.78 & 1 & 0.48 & 0.66 & 1 & 0.82 & 0.98 & \\
\hline 11 & 0.54 & 1.00 & 1 & 1.22 & 0.16 & 0 & 0.38 & 0.80 & 1 & 0.60 & 0.50 & 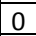 \\
\hline 12 & 0.40 & 0.94 & 1 & 0.88 & 1.10 & 1 & 0.72 & 0.72 & 0 & 0.66 & 0.12 & 0 \\
\hline 13 & 0.64 & 1.22 & 1 & 1.18 & 0.84 & 0 & 1.28 & 0.74 & 0 & 0.84 & 1.14 & \\
\hline 14 & 0.48 & 0.26 & 0 & 0.00 & 1.14 & 1 & \begin{tabular}{|l|}
0.58 \\
\end{tabular} & 1.30 & 1 & 0.58 & 0.84 & 4 \\
\hline 15 & 0.56 & 0.20 & 0 & 0.58 & 0.84 & 1 & 0.60 & 0.82 & 1 & 1.06 & 0.50 & 0 \\
\hline 16 & 0.06 & 0.18 & 1 & 0.70 & 1.00 & 1 & 0.92 & 1.16 & 1 & 0.72 & 0.90 & 4 \\
\hline 17 & 0.70 & 0.80 & 1 & 0.00 & 0.54 & 1 & 1.02 & 0.54 & 0 & 1.02 & 1.08 & 1 \\
\hline 18 & 0.30 & 0.54 & 1 & 0.36 & 0.68 & 1 & 0.20 & 0.28 & 1 & 0.44 & 0.56 & 1 \\
\hline 19 & 0.64 & 1.50 & 1 & 0.74 & 2.20 & 1 & 1.14 & 0.60 & 0 & 0.90 & 0.42 & 0 \\
\hline 20 & 1.84 & \begin{tabular}{|l|}
0.32 \\
\end{tabular} & 0 & 0.60 & 1.08 & 1 & \begin{tabular}{|l}
1.20 \\
\end{tabular} & 1.46 & 1 & 0.94 & 1.00 & 1 \\
\hline 21 & 1.82 & 0.86 & 0 & 1.94 & 1.22 & 0 & 1.06 & 0.52 & 0 & 0.48 & 1.26 & 1 \\
\hline 22 & 1.30 & 2.50 & 1 & 0.48 & 1.02 & 1 & 1.10 & 1.16 & 1 & 2.14 & 1.26 & 0 \\
\hline 25 & 1.60 & \begin{tabular}{|l|}
1.12 \\
\end{tabular} & 0 & 1.78 & 1.22 & 0 & \begin{tabular}{|l|}
0.66 \\
\end{tabular} & 1.78 & \begin{tabular}{|l|} 
\\
\end{tabular} & 1.22 & 0.82 & 0 \\
\hline 27 & 0.9 & \begin{tabular}{|l|l|}
1.14 \\
\end{tabular} & 1 & 1.48 & 0.9 & 0 & 0.98 & 1.06 & 1 & 0 & 0.12 & 1 \\
\hline 29 & 0.56 & 0.92 & 1 & 0.22 & 0.78 & 1 & 1.16 & 0.72 & 0 & 0.90 & 1.10 & 1 \\
\hline 30 & 1.38 & 1.22 & 0 & 0 & 0.64 & 1 & 0.8 & 0.76 & 0 & 1.04 & 1.24 & 4 \\
\hline 32 & 0.54 & \begin{tabular}{|l|l|} 
\\
\end{tabular} & 1 & 1.28 & 1.60 & 1 & \begin{tabular}{|l}
0.74 \\
\end{tabular} & 1.34 & 1 & 0.98 & \begin{tabular}{|l}
0.92 \\
\end{tabular} & 0 \\
\hline 34 & 1.16 & \begin{tabular}{|l|}
0.72 \\
\end{tabular} & 0 & 1.6 & 1.4 & 0 & 1.04 & \begin{tabular}{|l|}
0.9 \\
\end{tabular} & 0 & 0.64 & \begin{tabular}{|l|}
0.8 \\
\end{tabular} & 1 \\
\hline 36 & 1.12 & 1.38 & 1 & 1.10 & 1.74 & 1 & 1.30 & 1.06 & 0 & 1.28 & 1.20 & 0 \\
\hline 38 & 1.20 & 1.30 & 1 & 1.30 & 1.34 & 1 & \begin{tabular}{|l}
1.58 \\
\end{tabular} & 1.40 & 0 & 1.40 & 0.86 & 0 \\
\hline 41 & 1.16 & \begin{tabular}{|l|l|}
1.24 \\
\end{tabular} & 1 & \begin{tabular}{|l}
1.10 \\
\end{tabular} & 1.56 & 1 & 2.28 & 1.36 & 0 & 1.22 & 1.08 & 0 \\
\hline 43 & 1.20 & 1.26 & 1 & 1.74 & 1.20 & 0 & \begin{tabular}{|l}
1.12 \\
\end{tabular} & 1.40 & 1 & 1.30 & 1.60 & 1 \\
\hline 45 & 1.42 & \begin{tabular}{|l|}
0.92 \\
\end{tabular} & 0 & 1.30 & 1.12 & 0 & \begin{tabular}{|l|l|}
0.42 \\
\end{tabular} & 1.46 & , & 1.10 & 0.86 & 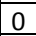 \\
\hline 47 & 1.10 & \begin{tabular}{|l|}
1.58 \\
\end{tabular} & 1 & 2.66 & 2.14 & 0 & 1.08 & 3.38 & 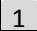 & 4.32 & 0.96 & 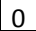 \\
\hline 49 & 2.04 & 1.20 & 0 & 0.98 & 1.84 & 1 & 1.84 & 0.96 & 0 & 1.00 & 1.54 & 1 \\
\hline 50 & 1.26 & \begin{tabular}{|l|l|}
0.16 \\
\end{tabular} & 0 & \begin{tabular}{|l}
1.10 \\
\end{tabular} & 1.56 & 1 & \begin{tabular}{|l}
1.20 \\
\end{tabular} & 0.96 & 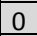 & 1.20 & 1.40 & \\
\hline 51 & 1.52 & \begin{tabular}{|l|}
0.52 \\
\end{tabular} & 0 & 1.30 & 1.78 & 1 & \begin{tabular}{|l|}
0.78 \\
\end{tabular} & \begin{tabular}{|l|} 
\\
\end{tabular} & \begin{tabular}{|l|} 
\\
\end{tabular} & 1.40 & 0.70 & 0 \\
\hline 54 & 0.28 & 3.30 & 1 & 3.70 & 3.28 & 0 & 1.78 & 2.80 & 1 & 3.48 & 2.92 & 0 \\
\hline & & $\Sigma C=$ & & & $\Sigma \mathrm{C}=$ & & & $\Sigma C=$ & & & $\Sigma \mathrm{C}=$ & \\
\hline
\end{tabular}

2006). Depending on the type of soil and slope of the area, the influence of leaching or runoff could vary, nevertheless $\mathrm{NO}_{3}$ concentration is expected to be higher for lower elevations and deeper layers, and this is reflected in the results for our study $\left(\mathrm{r}_{\mathrm{A}}=\right.$ 0.514 and $\mathrm{rho}_{\mathrm{A}}=-0.238 ; \mathrm{r}_{\mathrm{C}}=-0.785$ and $\mathrm{rho}_{\mathrm{C}}=-0.710$ ) as shown in Figure 2B. Other variables such as amount of dissolve oxygen present or permeability units on the soil (Cey et al., 1999, Selim et al., 1983; Ioka et al., 2001) affect the Nitrate concentrations in the area, but that analysis will be performed in another study.

\section{Yield Productivity:}

The strongest correlation was found between total yield and elevation with $\mathrm{r}=-0.750$ and $\mathrm{rho}=-0.768$ (Table 3), with a non-linear relationship reflected on a slightly higher rho value. Although there is a grape variety factor to be included in the analysis, the predominant behaviour is that at lower elevations the yield is slightly higher. In addition to elevation, there are some other factors that influence the vine productivity, such as $\mathrm{NO}_{3}$ concentrations, specifically at deeper layers $\left(\mathrm{r}_{\mathrm{C}}=0.609\right.$; $\left.\mathrm{rho}_{\mathrm{C}}=0.566\right)$.

Evidence of the sunshine influence on yield production is shown on Table 4, which presents the yield per cordon per plant location with respect to the soil sampling site; The ID represents the site location and $\mathrm{NWW}=$ North-West plant-West branch, NWE=North-West plant-east branch, and so on. Table 4 was constructed using a simple rule to determine which cordon of the plant produced more yield: If Yield $_{\mathrm{E}}>$ Yield $_{\mathrm{W}}$ then $\mathrm{c}=1$ otherwise $\mathrm{c}=0$, where Yield $_{i}$ is the plant yield (in $\mathrm{Kg}$ ) per cordon at East or West direction and $\sum \mathrm{c}$ represents the yield dependency with respect to the orientation. If $\sum \mathrm{c}>\mathrm{X}$, then the yield has strong correlation to the Eastern direction, for this case $X=19$ which is the critical value of total number of sampled sites divided by 2 . This rule simply reflects if more than half of the sampled plants had higher yield on the Eastern cordon, and if so then the sunlight could be a deterministic factor as far as vine yield was concerned.

Table 4 shows that there is a strong correlation between yield production and orientation, for all the NW, NE, SW and SE plants $\sum \mathrm{c}>19$, which means $10.5 \%$ of the sampled plants had more yield on the Eastern cordon than the Western side. This number was obtained from a simple calculation that out of 152 studied plants 91 produced more yield on the Eastern cordon. Table 5 presents the descriptive analysis and the correlation calculated for each side.

Table 5. Descriptive analysis of the plant's production per cordon orientation (East and West cordons)

\begin{tabular}{|c|c|c|c|c|c|c|c|c|c|c|c|c|c|}
\hline & \multirow{2}{*}{$\begin{array}{c}\mathrm{N} \\
\text { Statistic }\end{array}$} & \multirow{2}{*}{$\begin{array}{l}\text { Range } \\
\text { Statistic }\end{array}$} & \multirow{2}{*}{$\begin{array}{l}\text { Minimum } \\
\text { Statistic }\end{array}$} & \multirow{2}{*}{$\begin{array}{l}\text { Maximum } \\
\text { Statistic }\end{array}$} & \multirow{2}{*}{$\begin{array}{c}\text { Sum } \\
\text { Statistic }\end{array}$} & \multicolumn{2}{|c|}{ Mean } & \multirow{2}{*}{$\begin{array}{c}\text { Std. } \\
\text { Deviation } \\
\text { Statistic }\end{array}$} & \multirow{2}{*}{$\begin{array}{l}\text { Variance } \\
\text { Statistic }\end{array}$} & \multicolumn{2}{|c|}{ Pearson's } & \multicolumn{2}{|c|}{ Spearman's } \\
\hline & & & & & & Statistic & Std. Error & & & $r$ & Sig.(2t) & rho & Sig.(2t) \\
\hline East & 152 & 3.26 & 0.12 & 3.38 & 157.68 & 1.0374 & 0.04627 & 0.57045 & 0.325 & $0.408^{\star *}$ & 0.000 & $0.388^{* *}$ & 0.000 \\
\hline West & 152 & 4.32 & 0.00 & 4.32 & 150.84 & 0.9924 & 0.05086 & 0.62708 & 0.393 & $0.408^{* *}$ & 0.000 & $0.388^{* *}$ & 0.000 \\
\hline
\end{tabular}

Although, results from the yield/orientation are relevant at plant level, no correlation was found at the field level, once the mean value of orientation was introduced (see Table 6), the paired analysis did not reveal any statistical significance on the means of the sample groups (as Sig. 2-tailed is $>>$ than 0.05 ). 
Table 6. Paired Sample Test

\begin{tabular}{ccccccccc}
\hline & Mean & $\begin{array}{c}\text { Std. } \\
\text { Deviation }\end{array}$ & $\begin{array}{c}\text { Std. Error } \\
\text { Mean }\end{array}$ & Lower & Upper & t & df & $\begin{array}{c}\text { Sig. (2- } \\
\text { tailed) }\end{array}$ \\
\hline East -West & 0.0450 & 0.65299 & 0.05296 & -0.0597 & 0.1497 & 0.85 & 151 & 0.397 \\
\hline $95 \%$ Confidence Interval of the Difference & & & & & &
\end{tabular}

From mappings of the area, it is evident that there is an $18^{\circ} \mathrm{shift}$ of the field from the true southnorth direction, favouring more sunlight to the eastern branches of the vine. Calculating from the apparent motion of the Earth, which takes 24 hours to revolve 360 degrees $(360$ degrees/24 hours x 1 hour $=$ 15 degrees), we could infer that the eastern branches will receive about 2 more hours of sunshine than the western side (if the east side get one more hour and the west side one hour less, the difference between them is 2 hours). Further analyses are required to characterize and weight the relevant of parameters involve on the development and quality of wine grapes.

Finally, Figure 3 shows the soil nutrient distribution of interpolated values (Using Ordinary Kriging) for upper (Horizon A) and deeper layers (Horizon C). From these maps is clear to observe the Na concentration on the soil (Figure $3 \mathrm{a}$ and $3 \mathrm{~b}$ ) and how at lower elevations its concentration increases (on both layers). On the other hand, $\mathrm{NO}_{3}$ concentration shows its increment at lower elevation (Figure $3 \mathrm{c}$ and $3 \mathrm{~d}$ ). These figures are only an example of geostatistical tools and its application on precision agriculture. Further studies will be required to obtain improved mappings.
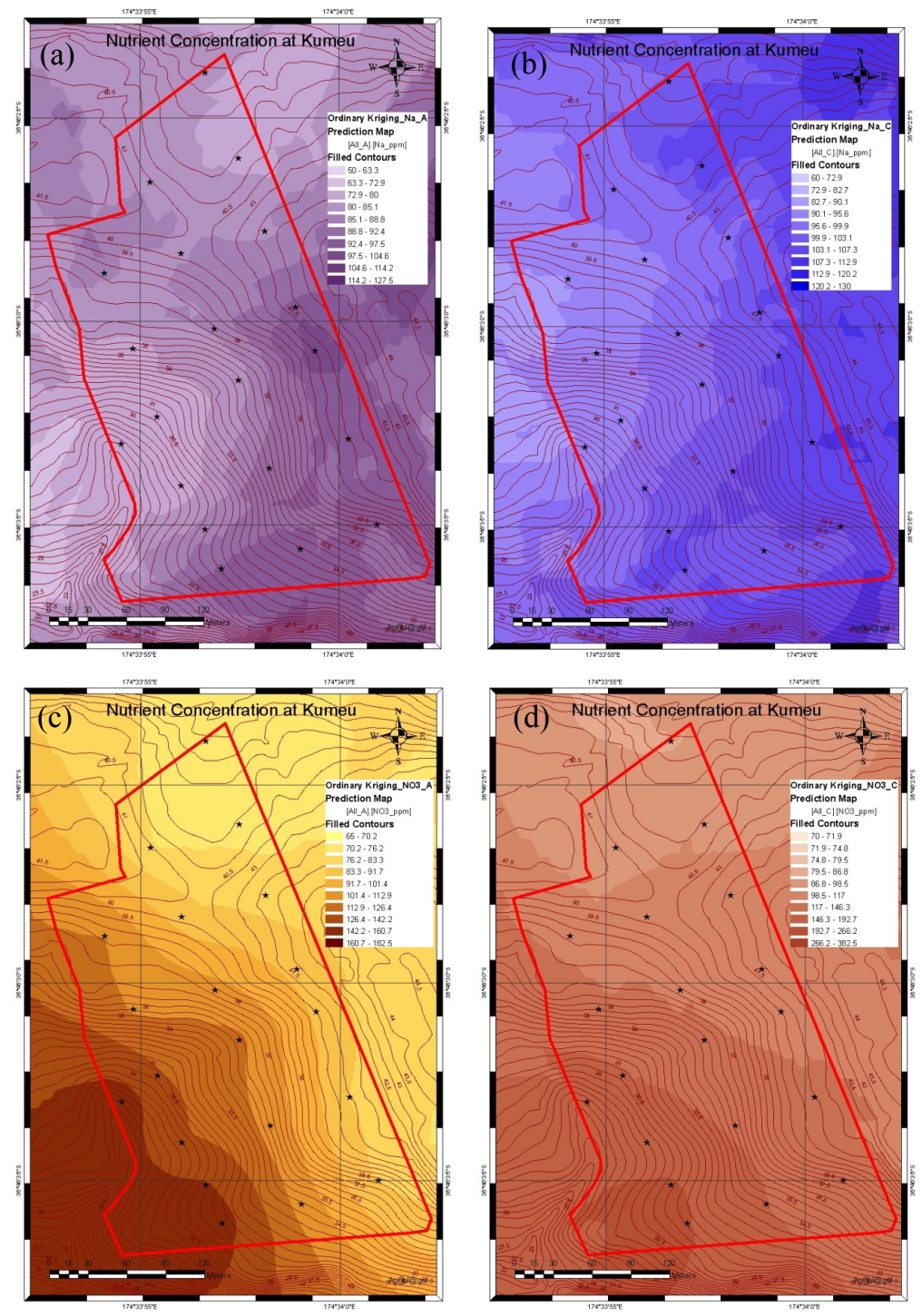

Figure 3. Soil Nutrient distribution obtained from Ordinary Kriging interpolation: $\mathrm{Na}$ concentration for (a) Horizon $\mathrm{A}$, (b) Horizon $\mathrm{C}$. $\mathrm{NO}_{3}$ concentration for (c) Horizon A. (d) Horizon C

\section{CONCLUSIONS}

Although this study represents a preliminary analysis of the data obtained during the harvest season (March 2011) at Kumeu River Winery, including preand post- harvest soil data, it is evident that the strong correlation found between the soil nutrient availability and the yield production, is caused by the topography of the vineyard. It should be noted that the availability of these nutrients depends on their cycle and interactions that in turn depend on the environment. However, another factor noteworthy of mention is that the study has revealed the inherent correlation between the sunlight hours and the yield production; of course another vital factor in this study is the quality of the grapes which is yet to be analysed. Calculations revealed that two more hours of sunshine could have contributed to the increase in the yield by $10 \%$ in the east branch hence more pruning is recommended to lessen sun-graced sides of the plant.

\section{ACKNOWLEDGMENTS}

Authors would like to acknowledge the 
Perez-Kuroki et al., Establishing the correlation between soil and crop production to optimize wine quality

collaboration provided by owner and Master of Wine, Michael Brajkovich from Kumeu River Winery, for his unconditional support and great scientific input given during the sampling and analysis process. Also we would like to thank Auckland Regional Council for providing aerial photos and high resolution elevation data to complete the study.

\section{REFERENCES}

Bates T. and Gee J. C. (2011). Nutrient Management. Retrieved from LERGP G.R.a.P.E website: http://lergp.org/book/export/html/35

Cey, E. E., Rudolph, D. L., Aravena, R. \& Parkin, G. (1999) Role of the riparian zone in controlling the distribution and fate of agricultural nitrogen near a small stream in southern Ontario. Journal of Contaminant Hydrology, 37(1999), 45 - 67. doi:10.1016/S0169-7722(98)00162-4

CRS 95/1. (2002). Sustainable Viticultural Production - Optimising Soil Resources. Final report to Grape and Wine $\begin{array}{lllll}\text { Research and Development } & \text { Corporation. } & \text { Retrieved } & \text { from }\end{array}$ http://www.gwrdc.com.au/webdata/resources/project/CRS951.pdf

Dami I., Bordelon B., Ferree D. C., Brown M., ellis M. A., Williams R. N. and Doohan D. (2005) Midwest Grape Production Guide. Bulletin 919-05. Retrieve from The Ohio State University Bulleting Extension: http://ohioline.osu.edu/b919/pdf/b919.pdf

Deb C. (2011). Grapevine Nutrition: Potassium Fertilisation. Retrieved from Informed Farmers website: http://informedfarmers.com/vine-potassium-fertilisation/

Elrashidil M. A., Mays M. D., Fares A., Seybold C. A., Harder J. L., Peaslee S. D., and VanNestel P. (2005) Loss of Nitrate-Nitrogen by Runoff and Leaching for Agricultural Watersheds. Soil Science 170(12), 968-984. Retrieved from

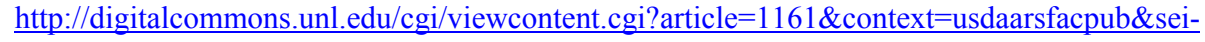
redir $=1 \#$ search=\%220038-075X\%2F05\%2F17012-969-984\%22

Gee J. C. (2011). Vineyard Design and Layout. Retrieved from LERGP G.R.a.P.E pages website: http://lergp.org/yearplanting/vineyard-design-and-layout

Hill R. B. and Sparling G. P. (2009) Chapter 3: Soil quality monitoring. In Land and Soil Monitoring: A guide for SoE and Regional Council Reporting; New Zealand. Published by the Land Monitoring Forum, New Zealand. Retrieve from http://www.envirolink.govt.nz/PageFiles/31/Land and soil monitoring. A guide for SoE and regional council reporting.PDF.

Ioka S., Tase N. and Toyama K. (2001). Relationship between the nitrate attenuation zone and groundwater flow in a typical hillslope-wetland plot in Japan. In Impact of Human Activity on Groundwater Dynamics (Proceedings of a symposium held during the Sixth IAHS Scientific Assembly at Maastricht, The Netherlands, July 2001). IAHS Publ. no. $269,2001$.

Jackson D. I. and Lombard P. B. (1993). Environmental and Management Practices Affecting Grape Composition and Wine Quality - A Review. American Society for Enology and Viticulture 44 (4), 409-430.

Joanes, D. N. and Gill, C. A. (1998) Comparing measures of sample skewness and kurtosis. Journal of the Royal Statistical Society (Series D): The Statistician 47(1), 183-189. doi:10.1111/1467-9884.00122

Kim N. D. and Taylor M. D. (2009). Chapter 5: Trace element monitoring. In Land and Soil Monitoring: A guide for SoE and Regional Council Reporting; New Zealand. Published by the Land Monitoring Forum, New Zealand. Retrieve from http://www.envirolink.govt.nz/PageFiles/31/Land and soil monitoring. A guide for SoE and regional council reporting.PDF

Ocampoa C. J., Sivapalana M.and Oldhama C. (2006). Hydrological connectivity of upland-riparian zones in agricultural catchments: Implications for runoff generation and nitrate transport. Journal of Hydrology, 331(3-4), 643-658. doi:10.1016/j.jhydrol.2006.06.010

Potvin C. and Roff D. A. (1993). Distribution-Free and Robust Statistical Methods: Viable Alternatives to Parametric Statistics. Ecology, 74(6), 1617-1628. Retrieved from http://www.onepoint.ca/Potvin and Roff 1993.pdf

Rodgers J. L. and Nicewander W. A. (1988) Thirteen ways to look at the correlation coefficient. The American Statistician, 42(1), 59-66. Retrieved from http://www.jstor.org/stable/2685263

Rouhana A. (2010). From vine to wine. Retrieved from Root Shoots and Fruits website: http://www.rd2.co.nz/uploads/From vine to wine.pdf

Selim H. M., Mehran M., Tanji K. K., Iskandar I. K. (1983). Mathematical simulation of nitrogen interactions in soils. Mathematics and Computers in Simulation, 25(3), 241-248. doi:10.1016/0378-4754(83)90100-3

Smart R. and Robinson M. (2006). Sunlight into Wine: A Handbook for Winegrape Canopy Management. Ashford, Australia: Winetitles PTY.

Spectrum Technologies. (n.d.a). FieldScout pH 100 Meter Manual [User's Manual]. Illinois, United States. Retrieved from http://www.specmeters.com/international/manuals.html

Spectrum Technologies. (n.d.b). Cardy Sodium Na+ Meter Manual [User's Manual]. Illinois, United States. Retrieved from http://www.specmeters.com/international/manuals.html

Spectrum Technologies. (n.d.c). Cardy Potassium K+ Meter Manual [User's Manual]. Illinois, United States. Retrieved from http://www.specmeters.com/international/manuals.html

Spectrum Technologies. (n.d.d). Cardy Twin Nitrate Meter Manual [User's Manual]. Illinois, United States. Retrieved from http://www.specmeters.com/international/manuals.html

White, R. E. (1987). Introduction to the principles and Practice of Soil Science - Chapter 13: Problem Soils (2 ${ }^{\text {nd }}$ ed.). Victoria, Australia: Blackwell Scientific Publications, ISBN 0-632-00052-X 